\title{
GERMINATION AND VIGOUR OF PRIMED ASPARAGUS SEEDS
}

\author{
Mário Lúcio de Carvalho Bittencourt ${ }^{1}$; Denise Cunha Fernandes dos Santos Dias ${ }^{2 *}$; Luiz Antônio \\ dos Santos Dias ${ }^{3}$; Eduardo Fontes Araújo ${ }^{2}$ \\ ${ }^{I}$ ESACMA - Depto. de Fitotecnia, Av. Dr. Athayde P. Sousa, s/n., Campus Universitário - 37750-000 - Machado, \\ $M G$ - Brasil. \\ ${ }^{2} U F V$ - Depto. de Fitotecnia, Campus Universitário - 36571-000 - Viçosa, MG - Brasil. \\ ${ }^{3}$ UFV/BIOAGRO - Depto. de Biologia Geral. \\ *Corresponding author $<$ dcdias@ufv.br $>$
}

\begin{abstract}
The osmotic conditioning or priming is considered a promising technique to speed up germination and to improve seed performance. Four seed lots of asparagus, Mary Washington cultivar, were primed at $25^{\circ} \mathrm{C}$ for seven or 14 days using PEG 6000 at -1.0 or $-1.2 \mathrm{MPa}$, or sea water at $-3.3 \mathrm{MPa}$; or for three days in distilled water. The physiological quality of the seeds was evaluated by standard germination, first count germination, speed of seedling emergence, and germination percentage and seedling fresh and dry weights after controlled deterioration test. Primed seeds presented higher germination speed, independently of their initial physiological quality. Beneficial effects of priming on germination and vigour were more expressive in the seed lot of low physiological quality. Priming in PEG 6000 at $-1.0 \mathrm{MPa}$ for 14 days was the most beneficial treatment to improve asparagus seeds performance.
\end{abstract}

Key words: Asparagus officinalis, osmotic conditioning, physiological quality

\section{GERMINAÇÃO E VIGOR DE SEMENTES DE ASPARGO OSMOTICAMENTE CONDICIONADAS}

\begin{abstract}
RESUMO: O condicionamento osmótico ou priming tem sido considerado uma técnica promissora para acelerar a germinação e melhorar o desempenho das sementes. Sementes de quatro lotes de aspargo, cv. Mary Washington, foram condicionadas em PEG 6000 a -1,0 e-1,2 MPa, por 7 e 14 dias, em água do mar a $-3,3 \mathrm{MPa}$, por 7 e 14 dias e em água destilada por 3 dias, em BOD a $25^{\circ} \mathrm{C}$. Sementes não condicionadas foram usadas como testemunha. A qualidade fisiológica das sementes foi avaliada pela germinação, primeira contagem de germinação, velocidade de emergência e pela porcentagem de geminação e pesos da matéria fresca e seca das plântulas obtidas no teste de deterioração controlada $\left(45^{\circ} \mathrm{C} / 24\right.$ horas). $\mathrm{O}$ experimento foi instalado no delineamento inteiramente casualizado com quatro repetições e oito tratamentos, sendo as médias comparadas pelo teste de Duncan a 5\%. Sementes de aspargo condicionadas osmoticamente apresentaram maior velocidade de germinação, independentemente de sua qualidade fisiológica inicial. Efeitos benéficos do condicionamento osmótico, na germinação e no vigor, foram mais expressivos no lote de baixa qualidade fisiológica. O condicionamento em PEG a -1,0 MPa por 14 dias foi, em geral, o tratamento mais adequado para promover melhoria na qualidade fisiológica dessas sementes.

Palavras-chave: Asparagus officinalis, condicionamento osmótico, qualidade fisiológica
\end{abstract}

\section{INTRODUCTION}

Depending on temperature and soil water potential, it takes from four to six weeks sowing to seedling emergence of asparagus. Techniques that speed up germination, such as seed priming, can enhance seed performance. This technique consists of seed imbibition in osmotic solutions with sufficient hydration to permit pregerminative metabolic events, but insufficient to allow radicle protrusion (Heydecker et al., 1975).

Salt solutions of $\mathrm{MgSO}_{4}, \mathrm{NaCl}$ and $\mathrm{KNO}_{3}$, and others have been used to obtain a controlled hydration of seeds (Haigh \& Barlow, 1987), and synthetic sea water (Frett et al., 1991) also has been used for this purpose.
According to Heydecker et al. (1975) polyethylene glycol (PEG 6000 or PEG 8000) is commonly used as osmotic-priming agent, because of its relatively inert and non-toxic nature. Seed priming response depends on several factors such as osmotic potential, temperature and duration of the treatment.

Beneficial effects from priming have been reported for many vegetables (Bradford, 1986). Priming has increased the rate and uniformity of germination and seedling emergence, especially under sub-optimal conditions such as low temperature (Warren \& Bennett, 1997; Demir \& Van de Venter, 1999; Demir \& Oztokat, 2003), salinity (Pill et al., 1991), water stress (Frett \& Pill, 1989) and heat (Warren \& Bennett, 1997). In asparagus, Krarup 
(1988) and Evans \& Pill (1989) reported that faster germination of primed seeds independ of treatment conditions, but priming has no effect on germination percentage. For tomato seeds, priming in synthetic seawater elicit greater germination percentage than PEG, but both were equally efficient in improving germination rate (Frett et al., 1991). However, Tiessen et al. (1983) concluded that priming did not improve asparagus seed performance. One reason for this discrepancy may be seed lot variation, that is, the beneficial effects of priming depend on seed vigour level (Bradford, 1986).

It is important, therefore, to evaluate the effects of priming on seed lots of different physiological quality. The objective of this study was to evaluate the effects of priming treatments on asparagus seed lots with different vigour levels.

\section{MATERIAL AND METHODS}

Seeds of four distinct seed lots of 'Mary Washington' asparagus (Asparagus officinalis L.) with 7.5 to $8.0 \%$ moisture contents were spread on two sheets of paper towel $\left(\mathrm{JProlab}^{\circledR}\right.$ - pH 6.5, density $68.4 \mathrm{~g} \mathrm{~m}^{-2}$, and resistance to rupture $2.67 \mathrm{~kg} \mathrm{~cm}^{-2}$ ) moistened with $20 \mathrm{~mL}$ of polyethylene glycol (PEG 6000) solution at -1.0 (296 $\left.\mathrm{g} \mathrm{L}^{-1}\right)$ or $-1.2 \mathrm{MPa}\left(326 \mathrm{~g} \mathrm{~L}^{-1}\right)$ according to Villela et al. (1991), or with natural sea water (-3.3 MPa osmotic potential), and kept in germination plastic boxes $(11 \times 11 \times$ $4 \mathrm{~cm}$ ) for either seven or 14 days. The sea water osmotic potential $\left(25^{\circ} \mathrm{C}\right)$, as determined by osmometer was 1.3672 Osmol, or 3,332 MPa. The period for each treatment was determined previously by Bittencourt et al. (2004a).

A sample of seeds was also imbibed in distilled water for three days. Fungal growth was controlled by adding $0.15 \%$ (a.i.) Captan to the solutions. All germination boxes were placed in an incubator at $25^{\circ} \mathrm{C}$. Non-primed seeds were used as control. After priming, seeds were rinsed in running tap water and then kept for three hours on towel paper $\left(25 \pm 2{ }^{\circ} \mathrm{C} ; 60 \% \mathrm{RH}\right)$ for superficial drying. The seeds were submitted to the following tests:

Seed moisture content: Determined by oven-drying duplicated samples at $130 \pm 3^{\circ} \mathrm{C}$ for one hour (Brasil, 1992). Percentage moisture content was expressed on a fresh weight basis.

Standard germination: Four replications of 50 seeds were distributed over three layers of paper towel $\left(\mathrm{JProlab}^{\circledR}\right)$ moistened with distilled water equivalent to three times the dry weight of the paper, in germination boxes, and incubated at $25^{\circ} \mathrm{C}$. The results were calculated as the average of four replicates of 50 seeds and expressed as a percentage by number of normal seedlings obtained at 13 days (first count) and 28 days after sowing (Brasil, 1992).

Speed of seedling emergence: Twenty-five seeds from each treatment were sown 3-mm deep in plastic trays
$(230 \times 160 \times 60 \mathrm{~mm})$ filled with moistened sand $(70 \%$ water retention capacity) to a depth of $40 \mathrm{~mm}$. Trays were kept at $25^{\circ} \mathrm{C}$ in a greenhouse. Emerged seedlings were counted daily for 23 days. The speed of seedling emergence was expressed in days and calculated according to Maguirre (1962).

Controlled deterioration: After each priming treatment, seeds were oven-dried $\left(30^{\circ} \mathrm{C}\right)$ back to $20 \%$ moisture. Non-primed (control) seeds were imbibed on moistened paper towel in an incubator at $25^{\circ} \mathrm{C}$ until they reached 20\% moisture. The target weight of seed samples at this moisture content was calculated according to Powell (1995). Once seed samples achieved the target weight, they were sealed in aluminium foil packet and held overnight at $10^{\circ} \mathrm{C}$. Samples then were placed in a waterbath at $45^{\circ} \mathrm{C}$ for 24 hours. Immediately after deterioration, germination tests were set up with four replicates of 50 seeds, as described above. The results were expressed as a percentage of normal seedlings obtained at 28 days after sowing

Seedling dry weight: Normal seedlings obtained at 13-days germination in the controlled deterioration test were weighed $(\mathrm{g})$ after seed coat removal. Seedlings dry weight $\left(\mathrm{mg}\right.$ seedling $\left.{ }^{-1}\right)$ was determined by drying in an oven at $70^{\circ} \mathrm{C}$ for 48 hours.

Statistical design and analysis: Trials were arranged in completely randomized block design $(n=4)$; data were subjected to analysis of variance, and differences between means separated by Duncan's test $(P=$ $0.05)$.

\section{RESULTS AND DISCUSSION}

Seed moisture content after priming ranged from 34.4 to $36.0 \%$, with no difference among the seeds from different treatments (data not shown). In general, priming increased total germination percentage (Table 1), especially for seed lot 1 (SL-1), in which germination increased from $40 \%$ (non-primed) to $61 \%$ with priming for 14 days in 1.2 MPa PEG. A minimum of $60 \%$ germination is required for marketing asparagus seeds in Brazil. Therefore, priming may improve germination to levels closer to commercial standards. For seed lot 2 (SL-2), with high initial germination percentage, there was no effect of any treatment. However, in SL-3, also with high physiological quality, positive effects were obtained with 14-day priming in 1.2MPa PEG. All priming treatments improved the germination of SL-4, except priming for 14 days in seawater. The initial seed quality has a marked effect on the success of the priming (Nascimento, 1998). However, Evans \& Pill (1989) did not obtain a priming benefit for asparagus seeds with high physiological quality.

All priming treatments improved germination at first count of SL-1, although the best results were obtained after priming for 14 days in -1.0 MPa PEG (Table 
2). For SL-2, PEG treatments at -1.0 MPa for seven days or at $-1.2 \mathrm{MPa}$ for seven or 14 days gave greater germination percentage than other treatments, while for SL-3 and SL-4, priming in -1.2 MPa PEG for 14 days resulted in the highest germination percentage. In general, a comparison among the lots showed that SL-1 and SL-4 had low and medium vigour, respectively, while the SL-2 and SL-3 had high vigour. The priming effects were more evident on the first count germination (Table 2) than on the total germination percentage, obtained 28 days after sowing (Table 1). Krarup (1991), Gray et al. (1991) and Heydecker \& Coolbear (1977) reported that the main effect of priming is increased germination percentage. In general, non-primed seeds had lower germination percentage independent of their vigour level, which justifies the use of priming for seed lots of both low and high physiological quality. The improvement in germination performance resulting from priming has been suggested as a result of repair mechanisms that occur during seed imbibition (Bray, 1995).
The speed of seedling emergence from nonprimed seeds was low, independent of the initial physiological quality (Table 3), but after priming in $-1.0 \mathrm{MPa}$ PEG for 14 days, the emergence of SL-1, SL-3 and SL4 was, on average, 4.6 days earlier than that of the control. For SL-2, all treatments, except sea water, enhanced speed of emergence as compared to the control. Priming in distilled water increased the speed emergence for all seed lots. These results reveal the benefit of priming asparagus seed lots of either low or high physiological quality. Krarup (1991) reported that while germination percentage of asparagus seeds was not affected by priming, the germination and emergence rates were increased. The fact that seed priming can increase germination rate is well-documented for several species (Heydecker \& Coolbear, 1977; Bradford, 1986; Evans \& Pill, 1989; Pill et al., 1991; Demir \& Van de Venter, 1999; Demir \& Oztokat, 2003; Nascimento, 2003). The beneficial effect of priming has been attributed to membrane repair, increased protein synthesis, and more ef-

Table 1 - Germination (28 days after sowing) of four asparagus seed lots subjected to different priming treatments.

\begin{tabular}{|c|c|c|c|c|}
\hline \multirow{2}{*}{ Treatment } & \multicolumn{4}{|c|}{ Seed lots } \\
\hline & 1 & 2 & 3 & 4 \\
\hline \multicolumn{5}{|c|}{ - } \\
\hline PEG - 1.0 MPa 7d & $54.5 \mathrm{ABb}$ & $92.0 \mathrm{Aa}$ & $95.5 \mathrm{ABa}$ & $90.5 \mathrm{Aa}$ \\
\hline PEG - 1.0 MPa 14d & $59.5 \mathrm{Ab}$ & $90.5 \mathrm{Aa}$ & $92.5 \mathrm{BCa}$ & $88.5 \mathrm{Aa}$ \\
\hline PEG - 1.2 MPa 7d & $50.5 \mathrm{Bb}$ & $91.5 \mathrm{Aa}$ & $95.5 \mathrm{ABa}$ & $93.0 \mathrm{Aa}$ \\
\hline PEG - 1.2 MPa 14d & $60.5 \mathrm{Ab}$ & $93.0 \mathrm{Aa}$ & $97.0 \mathrm{Aa}$ & $93.0 \mathrm{Aa}$ \\
\hline Seawater $-3.3 \mathrm{MPa} 7 \mathrm{~d}$ & $57.0 \mathrm{ABc}$ & $88.5 \mathrm{Aab}$ & $92.5 \mathrm{BCa}$ & $87.0 \mathrm{Ab}$ \\
\hline Seawater $-3.3 \mathrm{MPa} 14 \mathrm{~d}$ & $55.0 \mathrm{ABc}$ & $87.0 \mathrm{Aa}$ & $89.5 \mathrm{Ca}$ & $76.0 \mathrm{Bb}$ \\
\hline Distilled water $3 \mathrm{~d}$ & $49.0 \mathrm{Bb}$ & $89.0 \mathrm{Aa}$ & $90.0 \mathrm{Ca}$ & $87.0 \mathrm{Aa}$ \\
\hline Control & $40.0 \mathrm{Cc}$ & $90.0 \mathrm{Aa}$ & $92.0 \mathrm{BCa}$ & $80.5 \mathrm{Bb}$ \\
\hline C.V. $(\%)$ & 4.94 & & & \\
\hline
\end{tabular}

Means followed by the same letter, capital in each column and small in each row, did not differ by the Duncan's test $(P<0.05)$.

Table 2 - Germination at first count (13 days after sowing) of four asparagus seed lots subjected to different priming treatments.

\begin{tabular}{|c|c|c|c|c|}
\hline \multirow{2}{*}{ Treatment } & \multicolumn{4}{|c|}{ Seed lots } \\
\hline & 1 & 2 & 3 & 4 \\
\hline \multicolumn{5}{|c|}{ - } \\
\hline PEG - 1.0 MPa 7d & $40.0 \mathrm{Bb}$ & $91.0 \mathrm{Aa}$ & $95.0 \mathrm{ABa}$ & $88.5 \mathrm{ABa}$ \\
\hline PEG - 1.0 MPa 14d & $50.0 \mathrm{Ab}$ & $85.5 \mathrm{ABa}$ & $89.0 \mathrm{Ca}$ & $85.0 \mathrm{ABa}$ \\
\hline PEG - 1.2 MPa 7d & $40.0 \mathrm{Bc}$ & $91.0 \mathrm{Aa}$ & $94.5 \mathrm{ABa}$ & $84.5 \mathrm{ABb}$ \\
\hline PEG - 1.2 MPa 14d & $47.5 \mathrm{ABb}$ & $90.0 \mathrm{Aa}$ & $96.5 \mathrm{Aa}$ & $92.0 \mathrm{Aa}$ \\
\hline Seawater $-3.3 \mathrm{MPa} 7 \mathrm{~d}$ & $40.0 \mathrm{Bc}$ & $87.0 \mathrm{ABb}$ & $91.5 \mathrm{BCa}$ & $83.5 \mathrm{Bb}$ \\
\hline Seawater $-3.3 \mathrm{MPa} 14 \mathrm{~d}$ & $40.0 \mathrm{Bc}$ & $81.5 \mathrm{Ba}$ & $87.5 \mathrm{Ca}$ & $68.0 \mathrm{Cb}$ \\
\hline Distilled water $3 \mathrm{~d}$ & $28.0 \mathrm{Cc}$ & 87.0 ABab & $89.5 \mathrm{Ca}$ & $84.5 \mathrm{ABb}$ \\
\hline Control & $19.0 \mathrm{Dc}$ & $84.0 \mathrm{Ba}$ & $90.5 \mathrm{BCa}$ & $65.5 \mathrm{Cb}$ \\
\hline C.V. $(\%)$ & 5.77 & & & \\
\hline
\end{tabular}

Means followed by the same letter, capital in each column and small in each row, did not differ by the Duncan's test $(P<0.05)$. 
ficient mobilization of sugars and proteins (Srinivasan et al., 1999).

In the controlled deterioration test (Table 4), the germination percentage of SL-1 increased after all priming treatments, and the highest performance occurred after priming in sea water (seven and 14 days) and in PEG $-1.0 \mathrm{MPa}$ for 14 days. Using synthetic seawater may result in overpriming, because of its very low osmotic potential, a response not observed in PEG-primed seeds (Owen \& Pill, 1994). However, the observed lack of harmful effect on seed vigour could be attributed to the tolerance of asparagus seeds to salts (François, 1987). Priming did not enhance germination performance of SL2, SL-3 and SL-4.

The seed lot of lower physiological quality (SL1) had greater benefit from priming, especially after a stress condition, as obtained in the controlled deterioration test. Several authors reported benefits of seed priming on germination under stress conditions such as low and high temperatures (Demir \& Van de Venter, 1999;
Demir \& Oztokat, 2003; Bittencourt et al., 2004b). The effects of priming were less pronounced when priming was followed by controlled deterioration. When primed in PEG -1.0 MPa for 14 days seeds of SL-1, had their germination percentage doubled in comparison to the control (Table 4). Such improved germination of low vigour seed lots after priming and drying back was already observed by Tilden \& West (1985). Improved germinability of aged sunflower seeds by priming was associated with a lower rate of lipid peroxidation and higher antioxidant enzyme activities (Bailly et al., 2000).

Most priming treatments increased seedling dry weights (Table 5). In general, priming in PEG -1.0 MPa for 14 days was efficient for all seed lots, especially SL2. Increased seedling fresh and dry weights following priming was also registered for carrot seeds (Finch-Savage \& Pill, 1990). The fact that priming can increase germination rate is well-documented (Heydecker \& Coolbear, 1977). However, a question arises as to whether post-germination growth is also increased. The major ef-

Table 3 - Speed of seedling emergence of four asparagus seed lots subjected to different priming treatments.

\begin{tabular}{|c|c|c|c|c|}
\hline \multirow{2}{*}{ Treatment } & \multicolumn{4}{|c|}{ Seed lots } \\
\hline & 1 & 2 & 3 & 4 \\
\hline & (n) & - & (n- & (n) \\
\hline PEG - 1.0 MPa 7d & $15.78 \mathrm{BCa}$ & $11.85 \mathrm{Bb}$ & $10.38 \mathrm{Cc}$ & $11.81 \mathrm{Cb}$ \\
\hline PEG - 1.0 MPa 14d & $13.61 \mathrm{Da}$ & $10.66 \mathrm{Bb}$ & $9.36 \mathrm{Db}$ & $9.99 \mathrm{~Eb}$ \\
\hline PEG - 1.2 MPa 7d & $15.46 \mathrm{BCa}$ & $11.49 \mathrm{Bbc}$ & $10.67 \mathrm{Cc}$ & $11.84 \mathrm{Cb}$ \\
\hline PEG -1.2 MPa 14d & $14.59 \mathrm{CDa}$ & $11.57 \mathrm{Bb}$ & $10.50 \mathrm{Cb}$ & $10.87 \mathrm{Db}$ \\
\hline Seawater -3.3 Mpa $7 \mathrm{~d}$ & $16.95 \mathrm{ABa}$ & $13.04 \mathrm{Ab}$ & $12.61 \mathrm{Bb}$ & $13.12 \mathrm{Bb}$ \\
\hline Seawater -3.3 Mpa $14 \mathrm{~d}$ & $15.80 \mathrm{BCa}$ & $13.01 \mathrm{Ac}$ & $12.50 \mathrm{Bc}$ & $14.04 \mathrm{Ab}$ \\
\hline Distilled water $3 \mathrm{~d}$ & $16.06 \mathrm{BCa}$ & $10.80 \mathrm{Bb}$ & $10.81 \mathrm{Cb}$ & $11.46 \mathrm{CDb}$ \\
\hline Control & $18.24 \mathrm{Aa}$ & $14.06 \mathrm{Ab}$ & $14.01 \mathrm{Ab}$ & $14.71 \mathrm{Ab}$ \\
\hline C.V. (\%) & 6.04 & & & \\
\hline
\end{tabular}

Means followed by the same letter, capital in each column and small in each row, did not differ by the Duncan's test $(P<0.05)$.

Table 4 - Germination (28 days after sowing) in the controlled deterioration test of four asparagus seed lots subjected to different priming treatments.

\begin{tabular}{|c|c|c|c|c|}
\hline \multirow{2}{*}{ Treatment } & \multicolumn{4}{|c|}{ Seed lots } \\
\hline & 1 & 2 & 3 & 4 \\
\hline & (n) & (n) & - & - \\
\hline PEG - 1.0 MPa 7d & $40.5 \mathrm{BCb}$ & $80.0 \mathrm{Aa}$ & $81.0 \mathrm{ABa}$ & $78.5 \mathrm{Aa}$ \\
\hline PEG - 1.0 MPa 14d & $46.5 \mathrm{ABb}$ & $79.0 \mathrm{Aa}$ & $81.0 \mathrm{ABa}$ & $75.0 \mathrm{Aa}$ \\
\hline PEG - 1.2 MPa 7d & $38.5 \mathrm{Cc}$ & $79.5 \mathrm{Aa}$ & $84.0 \mathrm{Aa}$ & $70.5 \mathrm{Ab}$ \\
\hline PEG - 1.2 MPa 14d & $38.0 \mathrm{Cc}$ & $80.0 \mathrm{Aab}$ & $82.5 \mathrm{ABa}$ & $74.5 \mathrm{Ab}$ \\
\hline Seawater $-3.3 \mathrm{MPa} 7 \mathrm{~d}$ & $46.0 \mathrm{ABb}$ & $79.0 \mathrm{Aa}$ & $81.0 \mathrm{ABa}$ & $74.5 \mathrm{Aa}$ \\
\hline Seawater $-3.3 \mathrm{MPa} 14 \mathrm{~d}$ & $49.5 \mathrm{Ac}$ & $82.5 \mathrm{Aa}$ & $82.0 \mathrm{ABa}$ & $70.5 \mathrm{Ab}$ \\
\hline Distilled water $3 d$ & $34.0 \mathrm{Cb}$ & $76.0 \mathrm{Aa}$ & $77.0 \mathrm{Ba}$ & $73.0 \mathrm{Aa}$ \\
\hline Control & $24.5 \mathrm{Dc}$ & $76.5 \mathrm{Aab}$ & $79.5 \mathrm{ABa}$ & $70.0 \mathrm{Ab}$ \\
\hline C.V. $(\%)$ & 6.84 & & & \\
\hline
\end{tabular}

Means followed by the same letter, capital in each column and small in each row, did not differ by the Duncan's test $(P<0.05)$. 
Table 5 - Seedling dry weight at 13 days after sowing of four asparagus seed lots subjected to different priming treatments.

\begin{tabular}{lcccc}
\hline \multirow{2}{*}{ Treatment } & \multicolumn{4}{c}{ Seed lots } \\
\cline { 2 - 6 } & 1 & 2 & 3 & 4 \\
\hline PEG - $1.07 d$ & $0.0020 \mathrm{ABc}$ & $0.0034 \mathrm{Ba}$ & $0.0034 \mathrm{ABa}$ & $0.0028 \mathrm{ABb}$ \\
PEG -1.0 14d & $0.0025 \mathrm{Ac}$ & $0.0038 \mathrm{Aa}$ & $0.0037 \mathrm{Aa}$ & $0.0030 \mathrm{Ab}$ \\
PEG -1.2 7d & $0.0017 \mathrm{ABc}$ & $0.0031 \mathrm{Bab}$ & $0.0033 \mathrm{ABa}$ & $0.0027 \mathrm{ABb}$ \\
PEG -1.2 14d & $0.0024 \mathrm{Ac}$ & $0.0033 \mathrm{Bab}$ & $0.0034 \mathrm{ABa}$ & $0.0027 \mathrm{ABbc}$ \\
Seawater -3.3 MPa 7d & $0.0020 \mathrm{ABc}$ & $0.0034 \mathrm{Ba}$ & $0.0033 \mathrm{ABa}$ & $0.0026 \mathrm{Bb}$ \\
Seawater -3.3 MPa 14d & $0.0020 \mathrm{ABb}$ & $0.0032 \mathrm{Ba}$ & $0.0032 \mathrm{ABa}$ & $0.0029 \mathrm{ABa}$ \\
Distilled water 3d & $0.0025 \mathrm{Ab}$ & $0.0034 \mathrm{Ba}$ & $0.0034 \mathrm{ABa}$ & $0.0028 \mathrm{ABb}$ \\
Control & $0.0012 \mathrm{Bb}$ & $0.0031 \mathrm{Ba}$ & $0.0031 \mathrm{Ba}$ & $0.0026 \mathrm{Ba}$ \\
\hline C.V. $(\%)$ & 11.63 & & &
\end{tabular}

Means followed by the same letter, capital in each column and small in each row, did not differ by the Duncan's test $(P<0.05)$.

fect of seed priming on seedling growth resulted from earlier germination, which gave the seedlings more time to grow. Similar results were found by Nascimento \& West (1999) and Nascimento (2003).

SL-1 was inferior to SL-2, SL-3 and SL-4 in all treatments (Tables 1 to 5). In general, unprimed seeds of SL-2 and SL-3 showed similar physiological quality and were superior to SL-4. In general, primed asparagus seeds, regardless of priming conditions, germinated more rapidly than non-primed seeds (Table 3 ). Similar results have been obtained for asparagus seeds by Krarup (1991) and Gray et al. (1991). However, the beneficial effect of priming was more pronounced for seeds of low physiological quality, as also reported by Szafirowska et al. (1981), Bray (1995) and Nascimento \& Aragão (2004).

Effects of priming on seeds of different initial quality seems to depend on the stress that they encounter during germination. In general, PEG-priming at -1.0 for 14 days was the best treatment to improve asparagus seed performance, while priming in distilled water or seawater appeared to be less adequate. Probably, these results can be attributed to imbibitional damage in dry seeds caused by rapid imbibition in distilled water, leading to solute leakage and consequent cellular constituent losses (Heydecker at al., 1975). There is no consistent information regarding the use of natural seawater as the priming agent. Despite its osmotic potential being lower than that of PEG, no harmful effect on asparagus seed germination was found. However, seawater contains several ions which can penetrate the seed tissue, destroying enzymes or other cellular constituents, while PEG 6000 molecules have colloidal size and do not penetrate seed tissue. Hydropriming also improved performance of watermelon seeds, at low temperature, but was generally less effective than osmopriming in salt solutions (Demir \& Van de Venter, 1999). According to Evans \& Pill (1989), asparagus seeds primed for seven days in -0.8 MPa PEG showed higher germination, and synthetic sea water was as effective as PEG in accelerating seed germination (Frett et al., 1991).

Effect of priming improved seed performance in the controlled deterioration test (Table 4), but were generally more evident on germination at first count (Table 2 ), speed of seedling emergence (Table 3 ) and seedling growth (Table 5). Asparagus seeds primed in $-1.0 \mathrm{MPa}$ PEG for 14 days showed higher germination rate and speed of emergence independent of their physiological quality, but for all characteristics evaluated, beneficial effects of priming were more expressive on lower quality seed lots.

\section{REFERENCES}

BAILLY, C.; BENAMAR, A.; CORBINEAU, F.; CÔME, D. Antioxidant systems in sunflower (Helianthus annuus L.) seeds as affected by priming. Seed Science Research, v.10, p.35-42, 2000.

BITTENCOURT, M.L.C.; DIAS, D.C.F.S.; ARAÚJO, E.F.; DIAS, L.A.S. Controle da hidratação para o condicionamento osmótico de sementes de aspargo. Revista Brasileira de Sementes, v.26, p.98-104, 2004a.

BITTENCOURT, M.L.C.; DIAS, D.C.F.S.; DIAS, L.A.S.; ARAÚJO, E.F. Effects of priming on asparagus seed germination and vigour under water and temperature stress. Seed Science \& Technology, v.32, p.607-616, $2004 b$

BRADFORD, K.J. Manipulation of seed water relations via osmotic priming to improve germination under stress conditions. HortScience, v.21, p.1105-1112, 1986.

BRASIL. Ministério da Agricultura e da Reforma Agrária. Regras para análise de sementes. Brasília: SNDA, DNDV, CLAV, 1992. 365p.

BRAY, C.M. Biochemical process during the osmopriming of seeds. In: KGEL, J.; GALILI, G. (Ed.). Seed development and germination. New Cork: Marcel Dekker, 1995. p.767-789.

DEMIR, I.; VAN DE VENTER, H.A. The effect of priming treatments on the performance of watermelon (Citrullus lanatus (Thunb.) Matsum. \& Nakai) seeds under temperature and osmotic stress. Seed Science \& Technology, v.27, p. 871-875, 1999 .

DEMIR, I.; OZTOKAT, C. Effect of salt priming on germination and seedling growth at low temperatures in watermelon seeds during development. Seed Science \& Technology, v.31, p.765-770, 2003.

EVANS, T.A.; PILL, W.G. Emergence and seedling growth from osmotically primed or pregerminated seeds of asparagus (Asparagus officinalis L.). Journal of Horticultural Science, v.64, p.275-282, 1989. 
FINCH-SAVAGE, W.E.; PILL, W.G. Improvement of carrot crop establishment by combining seed treatments with increased seed-bed moisture availability. The Journal of Agricultural Science, v.115, p.75$81,1990$.

FRANCOIS, L.E. Salinity effects on asparagus yield and vegetative growth. Journal of the American Society for Horticultural Science, v.112, p.432-436, 1987.

FRETT, J.J.; PILL, W.G. Germination characteristics of osmotically primed and stored impatiens seeds. Scientia Horticulturae, v.40, p.171-179, 1989.

FRETT, J.J.; PILL, W.G.; MORNEAU, D.C. A comparison of priming agents for tomato and asparagus seeds. HortScience, v.26, p.1158-1159, 1991.

GRAY, D.; DREW, R.L.K.; BUJALSKI, W.; NIENOW, A.W. Comparison of polyethylene glycol polymers, betaine and L-proline for priming vegetable seed. Seed Science \& Technology, v.19, p.581-590, 1991.

HAIGH, A.M.; BARLOW, E.W.R. Germination and priming of tomato, carrot, onion, and sorghum seeds in a range of osmotica. Journal of the American Society for Horticultural Science, v.112, 202-208, 1987.

HEYDECKER, W.; COOLBEAR, P. Seed treatments for improved performance; survey and attempted prognosis. Seed Science \& Technology, v.5, p.353-425, 1977.

HEYDECKER, W.; HIGGINS, J.; TURNER, Y.J. Invigouration of seeds. Seed Science \& Technology, v.3, p.881-888, 1975.

KRARUP, A. Asparagus seed priming with magnesium sulphate and polyethylene glycol. Asparagus Research Newsletter, v.6, p.17, 1988.

KRARUP, A. Germinacion, emergencia y evaluacion de coronas de esparragos producidas a partir de semillas acondicionadas com polietilenglicol y sulfato de magnésio. Agro Sur, v.19, p.88-93, 1991.

MAGUIRRE, J.D. Speeds of germination-aid selection and evaluation for seedling emergence and vigor. Crop Science, v.2, p.176-177, 1962.

NASCIMENTO, W.M. Condicionamento osmótico de sementes de hortaliças: potencialidades e implicações. Horticultura Brasileira, v.16, p.106-109, 1998.

NASCIMENTO, W.M. Muskmelon seed germination and seedling development in response to seed priming. Scientia Agricola, v.60, p.71$75,2003$.
NASCIMENTO, W.M.; ARAGÃO, F.A.S. Muskmelon seed priming in relation to seed vigor. Scientia Agricola, v.61, p.114-117, 2004.

NASCIMENTO, W.M.; WEST, S.H. Muskmelon transplant production in response to seed priming. HortTechnology, v.9, p.53-55, 1999.

OWEN, P.L.; PILL, W.G. Germination of osmotically primed asparagus and tomato seeds after storage up to three months. Journal of the American Society for Horticultural Science, v.119, p.636-641, 1994.

PILL, W.G.; FRETT, J.J.; MORNEAU, D.C. Germination and seedling emergence of primed tomato and asparagus seeds under adverse conditions. HortScience, v.26, p.1160-1162, 1991.

POWELL, A.A. The controlled deterioration test. In: VAN DE VENTER, H.A. (Ed.) Seed vigour testing seminar. Copenhagen: ISTA, 1995. p.7387.

SRINIVASAN, K.; SAXENA, S.; SINGH, B.B. Osmo- and hydropriming of mustard seeds to improve vigour and some biochemical activities. Seed Science \& Technology, v.27, p.785-793, 1999.

SZAFIROWSKA, A.; KHAN, A.A.; PECK, N.H. Osmoconditioning of carrot seeds to improve seedling establishment and yield in cold soil. Agronomy Journal, v.73, p.845-848, 1981.

TIESSEN, H.; FITTS, M.; MAPPLEBECK, L. Influence of treating seed with nutrient solutions on the percent and rate of emergence of asparagus. Asparagus Research Newsletter, v.1, p.3, 1983.

TILDEN, R.L.; WEST, S.H. Reversal of the effects of aging in soybean seeds. Plant Physiology, v.77, p.584-586, 1985.

VILLELA, F.A.; DONI FILHO, L.; SEQUEIRA, E.L. Tabela de potencial osmótico em função da concentração de polietileno glicol 6000 e da temperatura. Pesquisa Agropecuária Brasileira, v.26, p.1957-1968, 1991.

WARREN, J.E.; BENNETT, M.A. Seed hydration using the drum priming system. HortScience, v.32, p.1220-1221, 1997.

Received July 02, 2004

Accepted May 9, 2005 